\title{
Fugitive Hydrography: The Nautical Magazine and the Hydrographic Office of the Admiralty, c.1832-1850
}

In December 1836, Captain Francis Beaufort, Hydrographer to the Navy, requested subsidy for an improving monthly periodical. Beaufort, head of the Hydrographic Office of the Admiralty, managed the production and publication of Admiralty sea charts and navigational texts. In making this request, he alluded to the range of information which routinely came in to his Office: notices of rocks and shoals, new lighthouses erected, buoys laid; new results from new means of observation; descriptions of ports increasingly used and often developing; accounts of changing practices of navigation; newly published and ever-updated charts. It was a maritime manifesto noting both the infrastructural development of the routes of the industrial revolution and the attempts to make maritime activity adequate to the spaces created by such change, giving a double sense of the improvement of the maritime world.[1] This constantly changing world required, Beaufort suggested, a regular, frequent publication strategy that a periodical easily permitted. That periodical, the blue-covered, octavo, shilling monthly Nautical Magazine, had been edited from its first appearance in March 1832 by Alexander Bridport Becher, chief Naval Assistant in the Hydrographic Office. [2] Following Beaufort's request, relating to a magazine that did not defray its own expenses, Becher would be allowed a sum of $£, 50$ a year for his role as editor.[3] It was the role of the state, Beaufort suggested, from the public office in which he worked, to provide support for a periodical such as this. Granted pecuniary stake outside of his salary, in a publication of professional concern which was always elided with civic concern, that relied on his role in the Office but was not part of it, Becher would go on editing the periodical until 1870.[4] 
Here I set out to describe the initiative taken, chiefly in relation to the hydrographic content and explicit self-presentation of the magazine, and the backstage work done at the Hydrographic Office by Francis Beaufort. The magazine is also used to examine the Hydrographic Office, at a time when it was managed by a naval officer also deeply involved in contemporary Whig-utilitarian projects such as the Society for the Diffusion of Useful Knowledge (SDUK). The magazine showed itself as an organ for the dissemination, but also crucially for the collection, of useful knowledge in its desire to improve the Royal and Merchant Navy. It also functioned to demonstrate an emergent community of maritime science, presenting the work of the Hydrographic Office of the Admiralty, and as a forum for the encouragement of engagement with naval science.

The paper explores ways in which the Magazine and its supporting institution within the Admiralty were taken up and characterized, chiefly using archival material related to the Magazine from the archive of the Hydrographic Office. It offers to the maritime historian a study of one of the most important British nautical journals of the nineteenth century; to the historian of nineteenth century print the somewhat surprising instance of an Admiralty supported magazine, and to the historian of science a suggestion for the importance of considering the relationship between contemporary projects of Useful Knowledge and the military state. After first outlining the naval context for the Nautical Magazine, this paper will examine the way in which certain elite figures were courted as readers and correspondents of the periodical. Then in examining the way in which navigational information was presented in the magazine, and how that related to routine submissions of documentation from Royal Naval vessels, it will suggest some of the editorial maneuvering involved in a periodical which sought and regulated contributions from a variety of sources. It will argue that this state supported Nautical Magazine was a knowingly prudent attempt to both suggest the existence of and to improve a maritime community. The periodical should be read as potent intervention in 
relation to the politically and socially fractious groups which existed around the Hydrographic Office in a period of strong, indeed utopian, belief in the socially and culturally transformative power of reading.[5]

I

The Hydrographic Office had been founded in 1795, originally as a department to organise and publish from the Admiralty's existing archive of charts and surveys and the routine submissions of navigational information from HM Ships. As such, it was always a publishing house. By the 1830s the Office had survey commissioning powers and a squadron of commissioned and hired vessels. Increasingly, surveying officers saw themselves as a distinct professional corps within the naval service.[6] Survey ships were employed surveying coastlines of particular commercial or colonial interest. Famously HMS Beagle went to South America, happening to have on board a certain young gentleman naturalist, but she was only one of around nine vessels whose officers and crews were involved in the intensive work of triangulation, astronomical and chronometrical position fixing, depth measurement, meteorological observation, drawing and writing which comprised hydrographic work. The published charts and sailing directions, drawn up in London, were provided to Royal Naval vessels, and from 1823 were also available commercially through chart agents in major port towns.[7] As well as commissioning surveys and publishing charts, the Hydrographic Office became increasingly involved with more general improvements to navigation, from giving verdict on newly developed navigational instruments to giving advice on the laying of buoys.

There was at the same time anxiety about the standing of the Hydrographic Office within the Admiralty and about hydrographic surveyors within the larger body of commissioned naval officers. Surveyors complained of how their work was seen as unnecessary by others. Their lack of standing in the service generally led to joining the surveying service being described in the Hampshire Advertiser as, in terms of career 
prospects, an act of "self-immolation." [8] The straightforward necessity of hydrographic surveying was in 1843 used in the Radical Hampshire Independent as another way to criticise the Admiralty's lack of commitment to what it suggested as an obvious public good.[9] On the other hand, the Office was also described in an angry critique of Admiralty spending by Charles Napier, known as the "Indiscreet Admiral", as a "humbug" which could be dispensed with.[10] More importantly, the First Secretary of the Admiralty until 1830, John Wilson Croker, had been a staunch opponent of the Hydrographic Office, seeing the office as wasteful expense and surveying as unnecessary diversion. [11] All of which is to suggest that a publication demonstrating both the work of the Hydrographic Office, and its utility, should be seen in part as an intervention in support of a branch of public administration.

There was longstanding, and deep, involvement of the Admiralty with the periodical and newspaper press. In this period, John Barrow as Second Secretary to the Admiralty expended much energy and ink controlling the image of the Navy in the press. He also contributed frequently to the Quarterly Review, as had John Wilson Croker, both of them fierce Tories.[12] And the news, frequently, was maritime: a significant amount of space was devoted in newspapers to arrivals and departures of merchant ships, movements of Royal Naval vessels, extracts from public dispatches, details of marine insurance, stories of shipwrecks. There had been much polemical space devoted in the reform debates to criticism of major maritime institutions: the Admiralty, the administrative body of the Royal Navy; the Board of Longitude, which worked in close connection with the Admiralty by this time with the broad remit of "improving navigation"; and the Nautical Almanac, which was published under the auspices of the Board.[13] Other elements of naval spending and management were standard targets in political debate, particularly naval architecture and dockyards, both of which were seen as offering ample opportunity for abuses of patronage. The Magarine occupied a 
specialist niche, but it was a niche in an obviously newsworthy and often controversial world.

There were other British periodicals explicitly devoted to naval or maritime matters. These range from the United Services Journal, which came out of the club for senior officers in the army and navy and was intended for that audience, through the short-lived British Log-Book (1837-1838) which principally offered stirring extracts from naval novels and voyage narratives, to the Sailor's Magazine, an evangelical periodical aimed at improving the religious disposition of seamen. The weekly "liberal conservative" Naval and Military Gazette and its rival the anti-reform United Service Gazette offered editorial and correspondence on service matters encompassing both army and Royal Navy.[14] It remains, however, that the bulk of maritime news, debate and comment took place outwith the pages of specifically nautical periodicals. Discussion of service matters in print was extensive enough that, by the mid-nineteenth century, there was concern about the damage that unregulated correspondence could do. In the 1844 Admiralty Instructions, was included the requirement that captains "caution the Officers under his command to refrain from writing in Newspapers, or other periodicals, on subjects connected with the Naval Service, such a practice being most injurious to its discipline and best interests."'[15] Questions of the propriety of periodicals relating to public service were raised in relation to the army as well as the navy. Hew Strachan notes that the Duke of Wellington refused to read the United Services Journal, and criticised that United Services Club for even subscribing to periodicals.[16] The financial support which the Nautical Magazine received from the Admiralty, then, has to be read alongside the periodical's place alongside the Hydrographic Office, and its associated apolitical posture and improving commitment.

As far as a periodical is always an exercise in audience making, the Nautical Magazine presents an interesting case. It does not, as a magazine coming out of a 
government survey office, offer those heights of dizzying reflexivity evident in the literary-political late-Regency periodicals which provided Jon Klancher's source material for The Making of English Reading Audiences.[17] It remains significant, however, that in its self-presentation the Nautical courted a wide readership, that in its "Original Papers" it accepted contributions from a range of writers, and in its use of correspondence suggested a forum for discussion of maritime affairs. Indeed, the Nantical has characteristics of earlier miscellanies with scientific content identified by Dawson, Noakes and Topham. Readers were understood as potential participants. Furthermore, the disciplinary fracturing indicated by the emergence of specialist scientific journals such as the Phrenological Journal (f.1820) or the Veterinarian (f.1825)[18] was not found in the Nautical, which proclaimed that navigation "is one vast science, the very essence of which is philosophy and which, in its most comprehensive form, embraces the sciences of Meteorology, Astronomy, Geography, and Hydrography."'[19] Indeed, the Magazine could be read as one of the alternatives Brian Maidment suggests for understanding cheap preVictorian miscellanies, as a "last gasp of an Enlightenment attempt to create a literate and well informed reading community that transcended class and nationality."[20] If it did so, however, the inclusion of the rank of named naval contributors clearly suggests the maintenance within the magazine's pages of the social stratifications of the maritime world.

It was not just a technical, professional journal, but sought to encourage higher navigational standards more broadly. In part this suggests something of the peculiar extent of this (proposed) maritime community: Royal and Merchant Navy; chronometer makers and navigation teachers; artisans and astronomers. What is clear from this range is the variety of work that went on in the pages of the Magazine, with turn by turn contributors seeking recognition for their newly developed instruments among potential buyers; trying to encourage scientific observation among naval readers; offering technical 
hints to equals; providing improving literature for a group of which the author was not strictly part.

The Magazine was formally separate from the Office. Nevertheless, correspondence related to the publication pervades the Hydrographic Office archive. Francis Beaufort's correspondents suggested content, and Alexander Becher's position as Naval Assistant in the Hydrographic Office allowed him access to those government records which provided the core material published in the magazine, and to certain esteemed contributors. The prospectus of the magazine in 1832 set out a periodical of four sections: Hydrography, which would give notice of reported dangers - rocks and shoals; Voyages, for entertaining review; Navigation, for notice of publications of charts, plans and sailing directions, and a Nautical Miscellany to be formed of notices of arrivals and sailings, wrecks, new steam routes, "and other intelligence of a miscellaneous and useful description.'[21] The structure of the periodical was not in in its realisation as consistent as the prospectus suggested. Nonetheless, in the period under consideration here, it remained a mixture of sailing directions, nautical notices, announcements of newly published charts, reports on voyages, original papers on nautical topics, letters to the editor, lists of ships in commission and notices of promotion, relevant extracts from newspapers of port towns, and naval births, deaths and marriages. Published monthly, and costing a shilling, issues varied between around 60 and 80 pages. It was published by Simpkin Marshall and in the early years printed by Fisher, Son and Company, which specialised in geographical works. Most issues would be accompanied by a lithographed, later an engraved, plate such as images of technical drawings to accompany the original papers, or reduced charts and harbour plans. In July 1836 it developed into an enlarged series, expanding the extent, if not necessarily the range, of the material included. In 1837, with the change of publisher, the printing and paper quality changed markedly 
without a corresponding change in price, economising in a publication whose sale did not cover its expenses.

There is little evidence for the circulation figures of the magazine. John Murray's limited involvement in the sale of the periodical between 1835 and 1839 was not successful, with only 24 copies sold in the four year period. By the later 1840s, the numbers were respectable. To accompany a memoir of the late John Barrow, Becher requested from John Murray 1,250 copies of a plate of him either from his Autobiographical Memoir (1847) or from his second volume of Arctic voyages (1846).[22] Furthermore, it was found in reading rooms as diverse as those of the United Services Club and the Preston Institution for the Diffusion of Useful Knowledge, expanding the potential readership beyond numbers of circulation.[23]

The most extensive attention in print which the Magazine received came from the Portsmouth, Portsea and Gosport Herald, part of the Hampshire Advertiser, which served a strongly maritime audience. Between 1834 and 1838 it included the Nautical almost monthly in its 'Literary Notices.' Alongside flattering notice of the Magazine's content and its utility came high praise for the patronage such a publication received. Such praise for patronage is unsurprising, particularly in a staunchly Tory newspaper. Still, it suggests how much such support for the periodical - which after all bore an image of William IV, the "sailor king," on its title page for its first five years - was acknowledged. There was never a question that this magazine was underwritten by the state.

\section{II}

The magazine also situated itself. The introduction to the first issue of the in March 1832 was a history of navigation written by Felipe Bauzà, the Spanish former Hydrographer. Bauzà had been exiled from Spain following the restoration there of absolutist rule in 1823, and in London, had found at the British Hydrographic Office a community of men acting in the service of the "vast science" of which his introduction 
provided a history.[24] As a text which argued for openness and communication in the development of hydrographic knowledge, it also demonstrated that which it lauded and for which it argued. Having a Hydrographer exiled from Spain for his liberal politics write the introduction to a magazine one purpose of which was to create and show a wider community engaged in matters of nautical science, particularly hydrography, demonstrated its potential power. It was a community which could welcome political exiles, a community presented through an explicitly communicative strategy, a community which, in the Nautical Magazine, could be presented as something like a republic of hydrography.

The letters to the Hydrographic Office from Beaufort's colleagues in St Petersburg, Paris, and Copenhagen confirm the sentiment. In correspondence, the European Hydrographers congratulated themselves on operating in a time when "national jealousies" no longer prevented the trigonometrical connections of coastlines of different countries.[25] The advantages for science and the common interests of those countries involved were invoked as part of the aching politeness involved in the regular chart exchanges established between Offices. Feodor Petrovich Lutke, the famed Russian navigator, was to write to Beaufort following a meeting with Frederick William Beechey, an experienced surveying captain whose work had by that time taken him to the Bering Strait in the searches for a North-west Passage, suggesting that the "Republic of Science" should be cosmopolitan "in the largest sense of the word", and that it was only right that hydrographers of different nations communicate with one another.[26] The metaphor of free exchange was explicitly suggested as literal by Beaufort, who, offering charts to the Danish Royal Library wrote that " $[\mathrm{t}]$ he freedom of Commerce, the safety of the mariner, and the interest of Science, alike demand an unrestricted interchange of the geographical acquisitions of all countries".[27] There was, alongside this, an insistence on the 
importance of hydrography to the "community" and to the "maritime world at large."'[28]

This is in part the context in which letters sent approving of the Nautical Magazine should be read. Adam Johann von Krusenstern, Russian circumnavigator, not only praised the publication after it was first sent to him, but also some years later, with congratulation that " $[\mathrm{t}]$ he excellent journal you have set going is a valuable acquisition to all nautical men, particularly to those living out of England.'[29] Christian Christopher Zahrtmann, Danish Hydrographer, lauded how the magazine showed the "activity displayed in surveying" on British coasts and beyond.[30] Lutke, similarly positive about the publication, concurred with the sentiments of useful knowledge expressed by the magazine, stating that "such a work, in the choice of articles and the popular manner of treating them, does infinitely more good and is a means a hundred times better for the propagation of useful knowledge than all those learned treatises, which few people read, and even fewer understand."'[31] The response was that this publication demonstrated what they all worked for, and this sense and their project was reinforced by their expressed willingness to contribute to the Magazine.

But these expressions of approval were not spontaneous. The first issues of the magazine sent to Copenhagen and St Petersburg were sent by Beaufort with accompanying letters. Approval of the Magazine from the elite of European hydrography had been commissioned, and commissioned with the language of useful knowledge: "knowing the great interest you take in the diffusion of hydrographical knowledge, I take the liberty of enclosing the $1^{\text {st }}$ number of the Nautical Magazine" wrote Beaufort to Krusenstern, "Amongst the means of support I know of none more powerful than the approbation of distinguished officers like you whose opinions must have such decided influence on those of the world.' [32] Writing to Zahrtmann, the British Hydrographer was even more explicit, suggesting, in a neat elision of the value of contributions from 
Copenhagen both to Becher as individual and to the face of the publication, that "The countenance and still more the assistance of enlightened foreigners like yourself would tend to give the work a character which would not only excite the editor to encreased exertions but which by opening to him fresh sources of information would render it still more worthy of their patronage."[33] Zahrtmann was also thanked, officially, by his British counterpart, for information provided.[34] This backstage work done by the Hydrographer, for a publication edited by someone within his Office, is an early example of the ambiguity of the publication. It embraced at once an acknowledgement of state support for a periodical aimed at a highly stratified audience, an insistence on the open exchange of knowledge, and a stated intention to "diffuse" it.

\section{III}

Alongside such impulses, a key sentiment of the Nautical Magazine was of the importance of open and communicated knowledge. In the 'Introduction' to the first volume, Bauzà suggested that what had previously retarded hydrography was a lack of a spirit of openness, that the "delay [in the improvement of Hydrography] arose from a fear of spreading the knowledge of coasts, the surveys of which were preserved in manuscript." The contemporary culture of European hydrography, however, was more open, and in its establishment of Offices and Depots provided a way of organising the material which had hitherto been unavailable, clearly in justification of the Hydrographic Office and its counterparts.[35] Stress was also placed on the importance of communication, with an earlier passage emphasising exchange in the development of knowledge using the example of Pedro Sarmiento de Gamboa, a sixteenth-century Spanish navigator most famous at this time for his voyage narrative relating to the Magellan Strait. Bauzà told how Sarmiento's instrument for measuring longitude "was lost because he did not make it known." [36] The contrast was thus drawn between the hoarding and protection of hydrographic and navigational knowledge of an earlier period 
and an emerging system facilitated not only by administrative bodies that made their work available, but also explicitly by publications like the Nantical. This echoes the sentiment expressed by those in the raging debates over institutional science in the 1820s, in which closed, secretive and corrupt bodies had been contrasted with the public virtue of the true philosopher. The contrast was particularly pointed since, as has already been mentioned, specially targeted in these attacks were key maritime institutions, the Board of Longitude, the Admiralty, and the Nautical Almanac.[37]

At the same time, the early magazine was adamant that its own existence was not profit-minded; oriented to improving commerce, perhaps, but not itself a commercial venture. At a shilling per issue, the Nautical was cheap in comparison with other contemporary monthly magazines. Where, mid-century, shilling monthlies such as the Combill Magazine explicitly made spectacle of economy through emphasising the technical wonder of production and the use of cheaper materials, the price of the Nautical Magarine was linked with the virtue of useful knowledge, and was understood to be patronised.[38] In 1839, an editorial reflection on the publication remarked on how the magazine stood apart from "the prevailing system (vice, we almost said) of booksellers, viz, that of making money."[39] It was a sentiment of useful knowledge, in a period when profit making through print could be morally suspect. Those same booksellers alluded to in the Magazine, and the obstructions they posed to knowledge, for example, were also attacked in Charles Babbage's fierce polemic in On the Economy of Machinery and Manufactures.[40] Five years after its first issue, stoically acknowledging that its circulation could be higher, the editorial voice was unequivocal. "We appeal to the sense of the British Nation - not to interested persons, for we are of no party, and we serve no private interest. Our purpose, regardless of all lesser designs, is to promote that first great object - the Public Good.”[41] In 1839, the Magazine would remark on its “proud station... of providing the most useful and most economical periodical extant" as well as the geographical extent of its 
circulation: the Nautical, dispersed in the naval world, could claim to have spread to the “further ends of the globe.”[42]

Locating itself within a world of proliferating print was a tactical endeavour, given expression in the Nautical Magazine by its direct comment on another periodical founded in 1832. In the second issue, notice was given of the Penny Magazine. This, it was said, unlike other publications with "pretensions to public utility" was devoid of those “political deformities" which made such works "offensive to well inclined persons.”[43] The praise of the "good sound information" of "general utility" contained within its pages created an interesting alliance with the Nautical itself, for which apolitical dissemination of useful knowledge was the proclaimed purpose. But this was not only a relationship between texts. The Hydrographic Office had a direct connection with the Penny Magazine: Beaufort was a member of the committee of the SDUK, acting as referee for various proposed publications and key member of the Society's Map Committee. The nature of Beaufort's duties at the Admiralty after 1829 meant that he was even better placed to compile maps for the Society.[44] The way in which he was able to draw on the stock of incoming hydrographic image and text as well as making use of well-placed correspondents[45] for his involvement with SDUK publications is comparable to the access Becher had to such material for the Nautical. At the same time, it has already been suggested that there was a certain useful knowledge rhetoric around the magazine itself, and a certain improving ethos which meant that much, if not all, of the biting satire and vituperative criticism that surrounded discussion of naval topics elsewhere was absent from the Magazine.

IV

In trying, as Beaufort described in a draught of the request for Admiralty subsidy in 1836, to develop an organ for the "general diffusion among seamen" of hydrographical knowledge, one of the standard parts of the Nautical Magarine was the nautical 
remarks.[46] The sources of these were various, but one important one was Remark Books from HM ships. These had long been a requisite annual return from Commanders and Masters in the Royal Navy, and were thus part of the routine of information which came into the Hydrographic Office. Among the various official documents required from Royal Naval vessels in this period, remark books count among the most idiosyncratic. Most comprised a mixture of tabulated information and other detail written out in full prose, but they could range from careful tables of positional and meteorological data to pages and pages of description, the detail from somewhat facetious accounts of fortifications, to that suggestive note from the Remark Book of a mail packet, repeated and each time covering a month, "No Opportunity for making any Remarks."[47] Assessments of them in Whitehall would range from the not infrequent "Nothing Remarkable" to their being "excellent" and their author worthy of specific thanks.[48]

Reporting to the Lords Commissioners of the Admiralty in 1827 on the role and function of the Hydrographic Office and those it employed, William Edward Parry, then Hydrographer, had given some comment on Remark Books, suggesting that amongst "a great deal that is useless and a mere matter of form" there was some information that was very valuable. Along with concern that few Captains knew what useful remarks to include might be, went a concern that often the value of the process of collection was not understood because it was not demonstrated. Thus it was also stated that publishing remarks submitted "would also be of great encouragement to Officers to send faithful \& accurate remarks, it being now a matter of frequent complaint that what is sent is not made use of." [49] The periodical showed a world in which - ideally - it was sustained because those who read also wrote, and in making passages and reporting them, an important part of the content of the magazine would continue to be reproduced. As a developing text, the Nautical Magazine can be seen to be fulfilling this, the ideal being that 
those reading the remarks published by others would become more confident in the value of the standard work they were required to do. Those remarks from Royal Naval officers, however, would still continue to be transmitted through the Hydrographic Office. At the same time, their publication in the Magazine might encourage those outside of the Captains, Commander and Masters required to submit remarks to the Admiralty, to provide their observations of particular coastlines to the periodical.

Among the Remark Books at the Hydrographic Office archive are those bearing the marks of their inclusion in the Nautical Magazine. Some are edited in pencil, and have at the end annotated notes to the printer on what to set up from submitted material, and what to include as editorial introduction. [50] Remarks might also have epistolary basis, as shown by a letter sent to Beaufort in 1839, which had been annotated for inclusion as remarks in the magazine.[51] A clarification sought by Becher about what he was allowed to publish also raises the question of what was public about hydrographic knowledge. Material had been sent from an officer serving in a ship on the Mediterranean Station, specifically for publication in the Nautical. An "officer of rank" had then suggested it was "contrary to the etiquette of the service" to encourage such communication. The correspondence between the two men suggested that it was in fact permissible for Officers to contribute to the Magazine, provided that this material would never include details of the operations or discipline of ships in commission. Unusually for communication between the two men in the same office, the reply from Beaufort was recorded in the Office's letter book.[52] A version of the request from Becher and the reply from Beaufort, sitting alongside one another, was published in the Nautical. Here, it advertised to potential readers that it would not be improper to contribute directly to the magazine, despite the Admiralty Instructions which discouraged officers from writing to newspapers and periodicals. [53] As such official sanction was given to a potential group of contributing writers which the Nautical sought to cultivate. 
Although the editing of the magazine took place outside of Becher's official duties, and outside the office, the blurring of the boundaries between the publication and the Office is shown by the numerous references to it in the letters into and out of the Hydrographic Office. When William Henry Smyth, a former surveyor and by that time important amateur astronomer, wrote in typically outspoken protest at a comment in the Nautical that his Harbour Plan of Villa Franca might have some more soundings, he wrote about it to Beaufort. He would not have complained, he suggested, except that he "considered those notices as demi-officials from your office," alluding to that genre of correspondence written between private persons in relation to, and supporting, and in some cases considered strictly necessary to, official business. [54] That his complaint was sent to Beaufort and not to Becher suggests how close the relationship between the Magazine and the Office was seen to be.

Some writing to Beaufort highlighted facts or papers for the Nautical, or requested that things be passed on to Becher; others lamented that the Magazine was not more widely known.[55] Still others expressed concern that the content of their letters to the Hydrographer might be made available to a wider audience. Bartholomew Sulivan, a surveying captain who undertook in the 1840s the survey of the Falkland Islands, wrote to Beaufort that "I should feel obliged sir if you would never allow any part of my letters to you to be put into the Nautical Mag.n except it is any thing relating to dangers at sea or information useful to vessels, that you may think it necessary to publish."[56] Sulivan wrote from the Rio de la Plata, where participation in the 1845 Anglo-French blockade had curtailed his surveying activities, so that any wider content of his letters might end up in the Magazine was perhaps unlikely. Still, what this suggests is the perception that, through the relationship between the Magazine and the Office, such publication was a very real possibility. 
Information did not just travel in one direction, from the Office into the Magazine. Beaufort would enquire after sources he imputed from published material in the magazine,[57] and would refer surveyors to the publication for details of work they might engage with, or use it to draw up accounts for such.[58] Information sent to the magazine would also be incorporated into the stock of the Hydrographic Office. Among remark books from the Mediterranean in the Hydrographic Office are a few pages of directions written by the master of a British merchant vessel. These had originally been sent to Robert Bate of the Poultry, who, as well as being a mathematical instrument maker and agent for Admiralty charts, was the London corresponding address for the Magazine (chart sub-agents in other port towns would also receive correspondence for the Magazine). In the Hydrographic Office, the directions are covered by a paper which includes the comment "Printed in the Nautical Magazine and present to the Office from that work.' [59] Becher's comment that the periodical had helped preserve otherwise "fugitive hydrography" goes some way to suggest the role the Magazine developed as something of a para-correspondence alongside that of the Hydrographic Office.[60] These letters also give some indication of the role of the editorial pen. The initial letter sent by R D Middleton, a merchant master, was in part a fervent attack on sailing directions published by a prominent London chart maker and publisher of nautical books, Norie, for the Mediterranean, which he described in the first letter to Bate as containing "gross nonsense" and being "a disgrace to the age".[61] The piece Middleton intended for publication was prefaced with comments about the "very erroneous" nature of Norie's work, with its "confused misstatements." [62] None of this finds a place in the Nautical Magazine. The edited manuscript shows alterations where "one might suppose that Norie had wished to increase the prevailing ignorance of this sea by his latest publication" was replaced with the more benign "A very erroneous opinion prevails also respecting the Western shore of this sea."[63] The vestiges of the criticisms directed at 
the work of a particular person are found in the title of the piece, "Observations on the Navigation of the Dardanelles, Bosphorus, and Black Sea, pointing out some of the defects in the directions at present in use, by R. D. Middleton, Master in the Merchant Service," or in the note that "the directions generally given for avoiding the shoals off Rabbit Island are not good.”[64] The requested anonymity for these directions, intended as outright polemic and published as information, was not granted. There was a very explicit sense in which navigational aids such as this had to bear a name to exhibit how far they might be trusted. In relation to charts, for instance, it was argued that the character of the surveyor could be the only guarantee for their work. [65] In the Magazine, what had been intended as anonymous invective was not permitted to surface as such. In letters to the editor, and in certain original papers, anonymous contributions were not unusual. However, in the Hydrographic sections of the Nautical, which included notes from the masters of merchant ships to established Royal Naval surveyors, the stratification of contributors to a field where credibility was based on rank and position was preserved.

\section{Conclusion}

Reflecting on the magazine in 1833, the Morning Post recognized that the endeavor to provide a periodical to show hydrography was also an endeavour to make an audience responsive to and receptive of the same. It suggested that the "great effort of the Magazine is to advance the knowledge of hydrography; but the editor wisely keeps it in view that that science, however beautiful in itself, is comparatively of no value unless used for the immediate purpose of making the world as one community."'[66] As such, it drew on the intense reflexivity of contemporary print culture, and a firm belief in the transformative power of print. It also recognized one aspect of a periodical which 
included contributions from a diverse, and widely distributed, naval and maritime readership. The Nautical Magazine, with its demi-official status and improving sentiment, was clearly rooted in the changing ideas of role of the state and the potential of the role of periodical literature in the 1830s. Oz Frankel has put forward the idea of the earlyVictorian state as a publisher, and in so doing draws attention to the array of texts produced under the auspices of, or in collaboration with, the state. His focus in relation to the British state is primarily on the publication of the Blue Books produced by social investigation, but the encouragement to think about the role of the state in the production of texts has obvious resonance with the state supported periodical under consideration here. One of Frankel's suggestions is to think about the state-as-publisher in the 1830 s as pervaded with impulses that also motivated publishing activities of, for example, the SDUK. At the same time, he highlights a desire to make visible, in selective ways, state activity coming out of the reform debates.[67] This provides a useful way of thinking about the Nautical Magazine in relation to the Hydrographic Office. This is particularly the case given the potential fruitfulness of considering the Hydrographic Office in the context of administrative reform and government expansion, and the links between the Office, through Francis Beaufort, to the SDUK itself. Although it is less clear cut, because of the demi-official status of the periodical, it is precisely this ambiguity that makes the magazine important to consider.

The Magazine claimed it stood for the community of nautical science. Coming out of the battles which raged in London, scientific and political, in the 1820s, and in a period when the place of reading and print was being redefined, claiming an audience was always a pointed manoeuvre. The venture of the Magazine was supported institutionally and financially by HM Government. In the magazine, the international aspect of the work was created by the backstage work of Francis Beaufort. The editorial pen changed the sentiment of submitted sailing directions. The reader-writer community 
suggested by the hydrography section of the Magazine was its argument and illusion, but also implicitly a justification of the work of the Office. The whole enterprise turned on the meanings of public in the Hydrographic Office's working: work resulting from duty on public service was itself public and thus publishable, needing to be presented to a public for the good of the public. It was done through a demi-official publication, the content of which both relied on, but was not part of, Becher's duties at the Admiralty.

In the case of the Nautical Magazine, the demonstrative function of the periodical, showing the work and the value of hydrography and through this hoping to achieve a maritime community adequate to it, suggests something important about the way in which those at the Hydrographic Office thought it valuable to present their operations. The explicitly developmental form of a monthly magazine meant that the ever necessary work of hydrography, and the development of maritime science more generally, could continue, be shown to continue, and attract contributors to whom the utility of this knowledge would be reciprocally demonstrated. One of the features of the Nautical Magazine is that whilst it did have its own correspondence, material contained in its pages was also that material sent into the Hydrographic Office as a matter of routine, whether in the form of remark books, sailing directions, or letters. That such information did not only travel one way suggests how in some ways the Magazine and the Office worked as the para-correspondences of each other. It presents an interesting case of state involvement in the periodical press by means of a magazine which sought not only to advertise and distribute, but also to encourage scientific, and particularly hydrographic, contributions. The very existence of the periodical suggests the perceived importance of journalistic techniques already evident in other areas of Admiralty involvement with the press. The attempt has been to examine the Nautical Magazine and its supporting institution from a standpoint which they themselves suggest. The paper was based on the premise that since the Magazine was in part intended to show the work of the 
Hydrographic Office, its examination will show something of that Office's working. What has been suggested here is how a certain image of public participation for the public good was created (through the utilization of privileged networks), managed (through making content acceptable), maintained (through negotiating the propriety of service contributions), and underwritten (through Admiralty subsidy) by the state. 


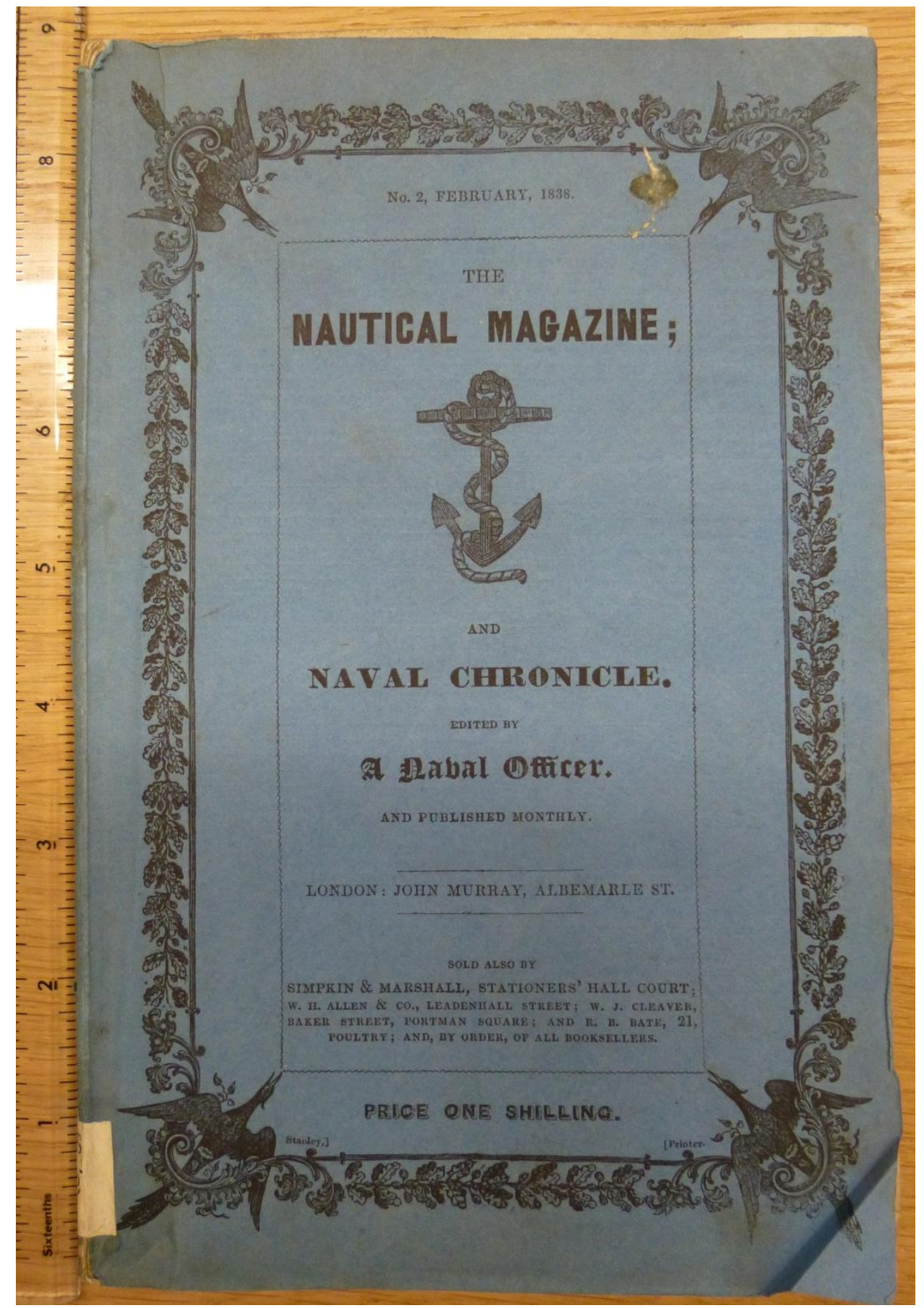

I: The blue cover of the Nautical Magazine, February 1838. National Maritime Museum FIS/62. 


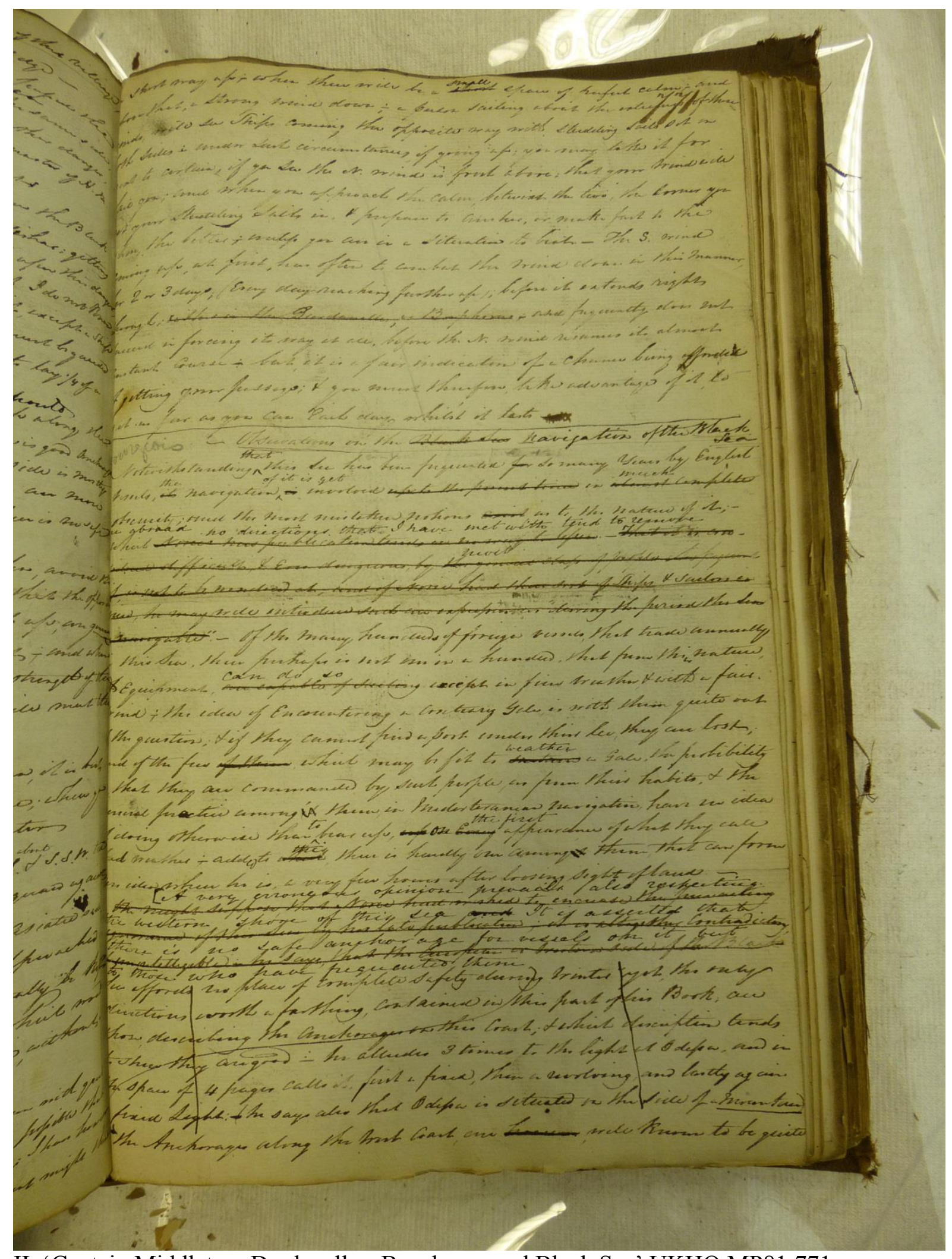

II: 'Captain Middleton: Dardanelles, Bosphorus and Black Sea' UKHO MP81:771 


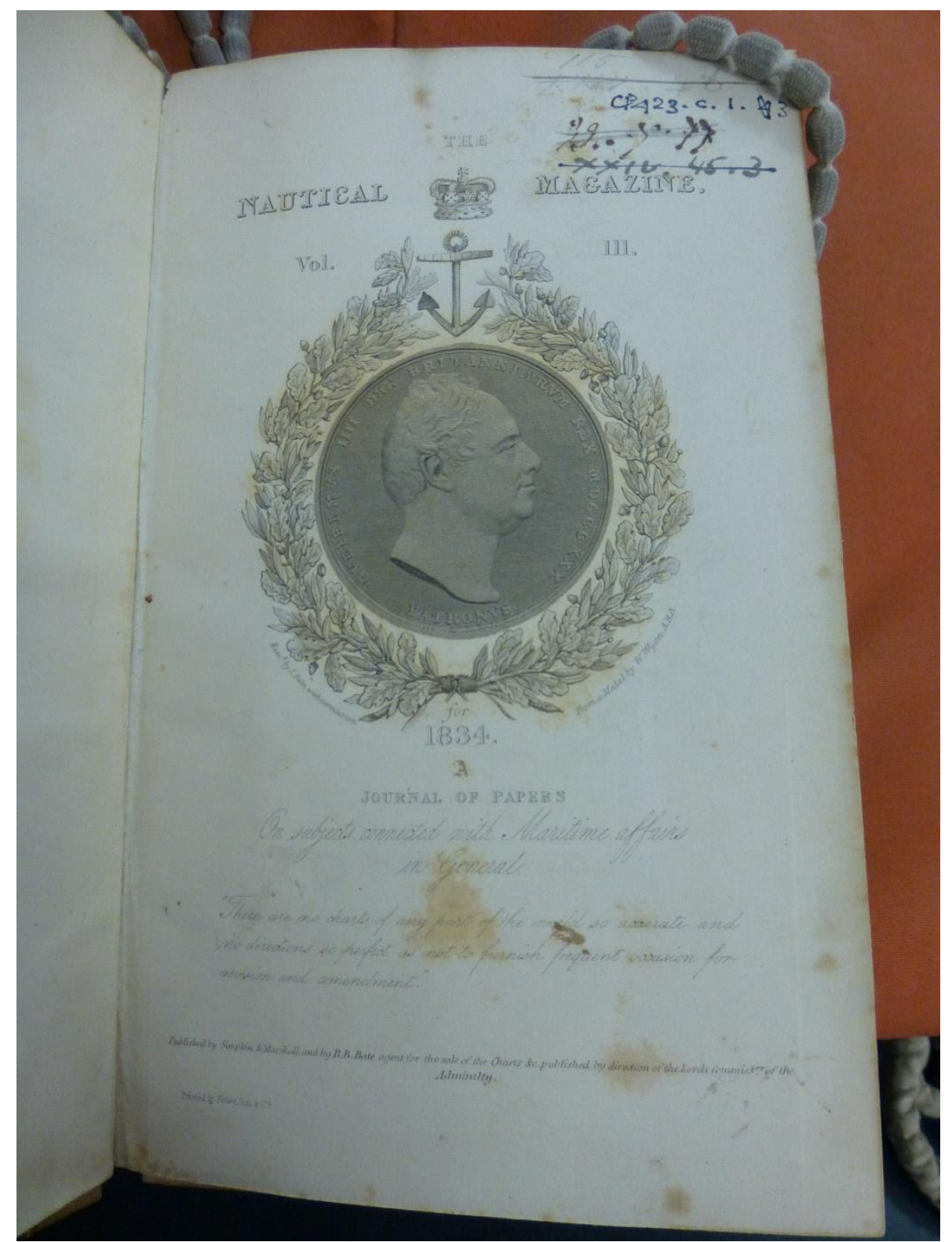

IV: Title page of volume III, 1834, showing the head of William IV surrounded by oak leaves, with anchor and crown. The motto of the Magazine reads: "There are no charts of any part of the world so accurate and no directions so perfect as not to furnish frequent occasion for revision and amendment." Cambridge University Library, CP423.c.3 


\section{References}

${ }^{1}$ The idea of improvement as both infrastructural and mutual develops the idea of maritime improvement suggested in Michael Bravo 'Geographies of Exploration and Improvement: William Scoresby and Arctic Whaling, 1782-1822' Journal of Historical Geography 32, no. 3 (2006), 512-538; Richard Drayton asserts the work of the Hydrographic Office as "one of the great monuments to British science" in his account of natural history and improvement centred on the long eighteenth century: Nature's Government: Science, Imperial Britain and the 'Improvement' of the World (New Haven, 2000), 126; it is also implicit in the account which Crosbie Smith gives in his description of the way the Nautical Magazine provided a forum for the exposition of technological improvements relating to steam ships: “We Never Make Mistakes”: Constructing the Empire of the Pacific Steam Navigation Company', in Miles Taylor, ed., The Victorian Empire and Britain's Maritime World, 1837-1901 (Basingstoke, 2013), 95-96, 101

${ }^{2}$ United Kingdom Hydrographic Office (hereafter UKHO), MB2:345-346 Francis Beaufort to the Admiralty Board, 20 December 1836

${ }^{3}$ UKHO/LP1857:B1521 John Barrow to Francis Beaufort, 23 February 1837

${ }^{4}$ The Magazine would continue until 2011, when was acquired by Sea Breezes

Publications, and amalgamated with their periodical publication, Sea Breezes:

http: $/ /$ www.seabreezes.co.im/index.php?option $=$ com content\&view $=$ article\&id $=745: \mathrm{m}$ essage-from-the-bridge-january-2012\&catid=1:editorial\&Itemid=146 [accessed 15

October 2014]

${ }^{5}$ Richard Altick The English Common Reader: A Social History of the Mass Reading Public (Chicago, 1957), 331; James Secord, Visions of Science: Books and Readers at the Dawn of the Victorian Age (Oxford, 2014), 14.

${ }^{6}$ David Miller 'The Revival of Physical Sciences in Britain, 1815-1840', Osiris, 2, (1986), 114. 
${ }^{7}$ Whilst the importance of the Hydrographic Office is sometimes alluded to, it remains an under-examined institution, and the main works on the Office come from within the institution itself: L S Dawson Memoirs of Hydrography [Eastbourne, 1885] (London, 1969); George Ritchie The Admiralty Chart: British Naval Hydrography in the Nineteenth Century (London, 1967); A Webb, The Expansion of British Naval Hydrographic Administration, 18081829 (Unpublished PhD thesis, University of Exeter, 2010). From outside of the office: R Cock, Sir Francis Beaufort and the Coordination of British Scientific Activity 1829-55 (Unpublished PhD thesis, University of Cambridge, 2003) deals specifically with Francis Beaufort, as does a biography, Alfred Friendly, Beaufort of the Admiralty (London, 1977).

${ }^{8}$ Hampshire Advertiser, 4 April 1840.

${ }^{9}$ Hampshire Independent, 29 July 1848.

${ }^{10}$ Charles Napier 'To The Editor Of The Times’ The Times (London), 26 December 1850.

${ }^{11}$ D P Miller 'Revival of Physical Sciences':113-114.

${ }^{12}$ Michael Bravo Science and Discovery in the Admiralty Voyages to the Arctic Regions in Search of a North-West Passage (1815-1825 (Unpublished PhD thesis, University of Cambridge, 1992), 105-111; Christopher Hamilton The Making of the Modern Admiralty: British Naval Policy Making, 1805-1927 (Cambridge, 2011), 97-99.

${ }^{13}$ Sophie Waring 'The Board of Longitude and the Funding of Scientific Work' Journal of Maritime Research 16, no. 1 (2014), 56-57.

${ }^{14}$ Huw Strachan Wellington's Legacy: The Reform of the British Army, 1830-1854 (Manchester, 1984):25, 22-23.

${ }^{15}$ Admiralty Instructions for the Government of Her Majesty's Naval Service (London, 1844):

Section II; Chapter V; no.9

${ }^{16}$ Hew Strachan Wellington's Legacy, 25

${ }^{17}$ Jon Klancher The Making of English Reading Audiences, 1790-1832 (Madison, 1987), 52-60. 
${ }^{18}$ Gowan Dawson, Richard Noakes and Jonathan Topham 'Introduction' in G Cantor et al, eds., Science in the Nineteenth Century Periodical: Reading the Magarine of Nature (Cambridge, 2004), 13

${ }^{19}$ Felipe Bauza 'Introduction' Nautical Magazine 1, no. 1 (March 1832), 3

${ }^{20}$ Brian Maidment 'Dinners or Desserts? Miscellaneity, Illustration, and the Periodical Press, 1820-1840’ Victorian Periodicals Review 43, no. 4 (2010), 377.

21 'Prospectus' Nautical Magazine 1, No.1 (March 1832), 2

${ }^{22}$ National Library of Scotland (NLS), John Murray Archive, BB Commission Book: NLS MS42884:151; NLS, John Murray Archive, MS40075:22ar-22br Alexander Becher to John Murray, 16 December 1848.

${ }^{23}$ 'Institution for the Diffusion of Useful Knowledge' Preston Chronicle 5 October 1833; 'Recent Additions and Donations' United Service Journal and Naval and Military Magazine (1838), 131.

${ }^{24}$ Ursula Lamb 'The London Years of Felipe Bauza: Spanish Hydrographer in Exile’ The Journal of Navigation, 34, (1981), 319-340.

${ }^{25}$ UKHO/MLP57/Denmark Christian Zhartmann to Francis Beaufort, 3 December 1838.

${ }^{26}$ UKHO/LP1857/L180 Fyodor Lutke to Francis Beaufort 25 March/3 April 1831.

${ }^{27}$ UKHO/LB4:241 Francis Beaufort to Christian Zhartmann, 13 February 13, 1833.

${ }^{28}$ Basil Hall ‘The Late Captain Hewett, of HMS Fairy’ Hampshire Telegraph 11 January 1841.

${ }^{29}$ UKHO/LP1857/K157 Johann von Krusenstern to Francis Beaufort, 10/27 May 1833;

UKHO/LP1857/K169 Krusenstern to Beaufort, February 1/13, 1844.

${ }^{30}$ UKHO/MLP57/Denmark Zahrtmann to Beaufort, 6 February 1835.

${ }^{31}$ UKHO/LP1857/L181 Lutke to Beaufort, 8/20 August 1833.

${ }^{32}$ UKHO/LB4:6 Beaufort to Krusenstern, 3 March 1832. 
${ }^{33}$ UKHO/LB4:6 Beaufort to Zahrtmann, 3 March 1832; also UKHO/LB4:295-296

Beaufort to Lutke 17 May 1833.

${ }^{34}$ UKHO/LB4:138 Beaufort to Zahrtmann, 12 September 1832.

${ }^{35}$ Felipe Bauzà 'Introduction' Nautical Magazine 1, no.1 (March 1832), 9.

${ }^{36}$ Felipe Bauzà 'Introduction’ Nautical Magazine 1, no.1 (March 1832), 2, 8.

${ }^{37}$ William Ashworth, 'The Calculating Eye: Baily, Herschel, Babbage, and the business of Astronomy' British Journal for the History of Science, 27, No.4 (1994), 414.

${ }^{38}$ Blackwood's Edinburgh Magarine, for example, cost 2s6d; on shilling monthlies: Gowan

Dawson, 'The Cornhill Magazine and shilling monthlies in mid-Victorian Britain' in

Dawson et al Science in the Nineteenth Century Periodical, 123.

39 'To our friends and correspondents' Nautical Magazine, 8, No.1 (January 1839), 71.

${ }^{40}$ Charles Babbage, On the Economy and Macbinery of Manufactures $3^{\text {rd }}$ ed (London, 1833), $\mathrm{x}-$ xii.

41 'Ourselves to Our Constituents’ Nautical Magazine, 6, No.1 (1837), 2.

42 'To Our Friends and Correspondents' Nautical Magazine, 8, No.1 (January 1839), 71.

43 'Editors Notes,' Nautical Magazine, 1, no.2 (April 1832), 99.

${ }^{44}$ Mead Cain, 'The Maps of the Society for the Diffusion of Useful Knowledge: A

Publishing History', Imago Mundi, 46 (1994), 156.

${ }^{45}$ UKHO/LB8:246-7 Beaufort to Henry Bayfield 1 May 1839, asks for his judgement of a plan of Quebec prior to giving it to the SDUK for publication.

${ }^{46}$ UKHO MB2:344 Minute by Beaufort, no date, cancelled.

${ }^{47}$ UKHO/MP56:578 Remark Book of the Ranger; UKHO/MP56:634-635 Remark

Book of the Cygnet

${ }^{48}$ Master's Remark Book, HM Ship Collingwood, 1848, UKHO/CRB1848:AH;

UKHO/CRB1844 Remark Book of the Modeste, 1844. 
${ }^{49}$ UKHO/MLP5:3ii:10,11 William Parry 'Notice Respecting the Establishment of the Hydrographic Office’ 1 February 1827.

${ }^{50}$ UKHO/CRB1834-1835 J G Northcote, Remarks, HMS Nimrod; in print: 'Remarks on the Harbour of Santander' Nautical Magarine 4, No.39 (1835), 263-264.

${ }^{51}$ UKHO/CRB1840 John Hindmarsh to Beaufort, 2 February 1839.

${ }^{52}$ UKHO/LP1857/B189 Alexander Becher to Beaufort, 13 June 1843;

UKHO/LB11:190 Beaufort to Alexander Becher, 16 June 1843.

53 'The Nautical Magazine’ Nautical Magazine, 12, (July 1843), 501.

${ }^{54}$ 'Charts’ Nautical Magazine 2, No.20 (October 1833), 606; UKHO/SL5 William Henry Smyth to Francis Beaufort, 2 October 1833.

${ }^{55}$ For instance: UKHO/SL19a:25 Beaufort to Phillip Parker King, 1 October 1 1838;

UKHO/LP1857/R294 R Robertson to Beaufort, 15 October 1834;

UKHO/LP1857:B1529 Peter Barlow to Beaufort, 15 August 1837; UKHO/SL113

Frederick William Beechey to Beaufort, 2 April 1836; UKHO/SL104 Henry Bayfield to Beaufort, 13 February 1833; UKHO/LP1857/H877 James Everard Home to Beaufort, 7 March 1845; UKHO/SL2a Thomas Mudge to Beaufort, 8 September 1833.

${ }^{56}$ UKHO/SL18c Bartholomew Sulivan to Beaufort, 30 September 1845.

57 “'In looking over these directions [reprinted from the Moreton Courier in the Nautical Magazine] it is evident that they are intended to refer to some particular plan of the Bay are several points and buoys are named of which in this Office we know nothing. Should such a plan have been published in Australia I beg you will make a point of procuring and forwarding to me as early as possible after your arrival..." UKHO/LB15:98-99 Beaufort to John Lort Stokes, 11 January 1848.

${ }^{58}$ UKHO/MB3:419 Surveying Instructions to Henry Blackwood, 29 March 1842.

${ }^{59} \mathrm{UKHO} / \mathrm{MP} 81: 761,1833$. 
${ }^{60}$ [Alexander Becher], 'The Editor's Farewell', Nautical Magazine, 39, no.12 (December 1870), 699.

UKHO/MP81:783 R Middleton to Robert Bate, January 14, 1833.

${ }^{61} \mathrm{UKHO} / \mathrm{MP} 81: 762,1833$.

${ }^{62} \mathrm{UKHO} / \mathrm{MP} 81: 771,1833$.

${ }^{63}$ Robert Middleton, 'Observations on the Navigation of the Dardanelles,' Nautical

Magazine, 2, No.13 (March 1833), 113.

${ }^{64}$ Basil Hall 'The Late Captain Hewett, of HMS Fairy’ Hampshire Telegraph 11 January 1841.

${ }^{65}$ 'The Nautical Magazine’ Morning Post (London) 8 January 1833.

${ }^{66} \mathrm{Oz}$ Frankel States of Inquiry: Social Investigations and Print Culture in Nineteenth-century Britain and the United States (Baltimore, 2006), 47-59 